\title{
Structural Performance Evaluation of Landolphia buchananii Shear Reinforced Concrete Beams
}

\author{
M. K. Kettera , E. Nsabimana ${ }^{a}$

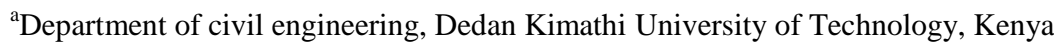

\begin{abstract}
This study aims to evaluate the performance of Landolphia buchananii shear reinforced concrete beams to establish the potential of Landolphia buchananii as a shear reinforcement of concrete beams. Tensile strength test on Landolphia buchananii was performed and reinforced concrete beam test was done. The performance of Landolphia buchananii shear reinforced concrete beam was compared to that of steel shear reinforced concrete beam. Varying size/area of shear reinforcement of Landolphia buchananii was used for beam specimen made of concrete of average compressive strength of $20.8 \mathrm{~N} / \mathrm{mm}^{2}$. The results showed that the failure loads increased with increase in area/size of shear reinforcement. Tensile strength of Landolphia buchananii was found to be 65 percent lower than that of conventional mild steel. The study showed that Landolphia buchananii can be used as shear reinforcement in concrete beams and can be used as a substitute of steel under low loading regimes.
\end{abstract}

Keywords: Landolphia buchananii, reinforced concrete beam, shear link, bending, crack, deflection

\section{Introduction}

Steel is majorly used as a reinforcement in concreted due it its high tensile strength which compliments concrete low tensile strength. However, use of steel in construction has its own limitations; it is costly, energy consuming and carbon dioxide (CO2) emitting during manufacturing process [1]. These limitations have led to increasing interest in the possible use of alternative locally available materials for the reinforcement of concrete. Research has been done on several vegetable fibres as reinforcements of concrete. Bamboo [1-7], mangrove [8-9], babadua [10], rattan cane [11-12] and palmyrah [13] has been studied as a possible reinforcement of concrete to evaluate its performances as concrete reinforcement material.

This study focuses on Landolphiabuchananii stem as one of the vegetable fibres. The study will focus on the structural capabilities of Landolphiabuchananii as shear reinforcement in concrete. Landolphiabuchananii is a flexible forest liana and sprawling shrubs with latex filled stems, jasmine-scented flowers and fruits growing up to forty meters tall and twenty centimetres in diameter [14]. It grows in Eastern Africa, Central Africa and parts Western Africa [15].

Experimental investigation and evaluation of the use of Landolphiabuchananii stem as shear reinforcement material in concretes has been presented in this paper. The experimental program, tests results and discussion and conclusion has been dealt with in this paper.

\section{Materials, Sample Preparation, Mix Design and Concrete Beam Preparations}

\subsection{Materials}

a) Cement: Local Portland Pozzolona cement manufactured to Standard Specification KS EAS 18-1: 2001 and classified as CEM IV/B-P 32.5N Portland Pozzolana cement. b) Coarse aggregate: Coarse aggregate of maximum size of $20 \mathrm{~mm}$ as specified in accordance to BS 882[16].

c) Fine aggregate/Natural sand: Normal River sand as specified in accordance to BS 882[16].

d) Landolphia buchananii stems: Obtained from Nandi forest in western Kenya. The diameters of the stems varied from $6 \mathrm{~mm}$ to $13 \mathrm{~mm}$.

e) High yield twisted and mild steel bars: $12 \mathrm{~mm}$ and $6 \mathrm{~mm}$ diameter respectively as specified in accordance to BS 8110 [17].

\subsection{Sample preparation}

\subsubsection{Landolphiabuchananii stems}

Stems of uniform cross-sections along the length were selected and their bark removed. For each stem, the diameters were measured at three positions and then averaged; the positions were at the two ends and the middle of the stems. For tensile and shear tests, the test specimens were prepared in accordance to BS 373 [18].

\subsection{Concrete mix preparation}

Concrete standard nominal mix proportion of 1:2:4 by volume which is expected to yield a target compressive strength of $20 \mathrm{~N} / \mathrm{mm}^{2}$ at the age of 28 days was adopted from British Standard BS 8500[19]. To maintain workability and avoid excess water which can cause the swelling of the stem, the slump value was maintained at $30-40 \mathrm{~mm}$

\subsection{Reinforced concrete beam specimens}

Beams with varying areas of shear reinforcement were used. There were five beams each with longitudinal reinforcement of $12 \mathrm{~mm}$ diameter high yield twisted steel, two at both top and bottom. One of the five beams was purely reinforced with steel to act as a control while the rest were reinforced with Landolphiabuchananiias shear reinforcements. Shear links spacing was maintained at 200 $\mathrm{mm}$ centre to centre for all the beams. Beams were of $1100 \mathrm{~mm}$ length, $150 \mathrm{~mm}$ width and $250 \mathrm{~mm}$ depth. The 


\section{International Journal of Science and Research (IJSR) \\ ISSN (Online): 2319-7064 \\ Index Copernicus Value (2013): 6.14 | Impact Factor (2014): 5.611}

diameters /size of shear reinforcement was $6 \mathrm{~mm}, 8 \mathrm{~mm}$, $2 \times 10 \mathrm{~mm}$ and $2 \times 13 \mathrm{~mm}$ for Landolphiabuchananii reinforced and $6 \mathrm{~mm}$ for steel reinforced.

Concrete was compacted with poker vibrator and a concrete cover of $20 \mathrm{~mm}$ to links was maintained. Specimens were then cured for 28 days in wet conditions. Concrete cubes of $150 \times 150 \times 150 \mathrm{~mm}$ were cast alongside the beams and cured in a water tank for 28 days. Figure 1 show steel fixed with Landolphiabuchananii as shear links.

The following notations have been use throughout this paper for ease identification throughout this paper:

L.B.1x6: Beam with 2Y12 top and bottom and $L$. buchananii shear links of diameter of $6 \mathrm{~mm}$ with spacing of 200mm.

L.B.1x8: Beam with 2 Y12 top and bottom and $L$. buchananii shearlinks of diameter of $8 \mathrm{~mm}$ with spacing of $200 \mathrm{~mm}$.

L.B.2x10: Beam with 2 Y12 top and bottom and $L$. buchananii double shear links of diameter of $10 \mathrm{mmwith}$ spacing of $200 \mathrm{~mm}$.

L.B.2x13: Beam with 2 Y12 top and bottom and $L$. buchananii double shear links of diameter of $13 \mathrm{mmwith}$ spacing of $200 \mathrm{~mm}$.

Steel 1x6: 2 Y12 top, 2 Y12 bottom, R6 links spacing $200 \mathrm{~mm}$.

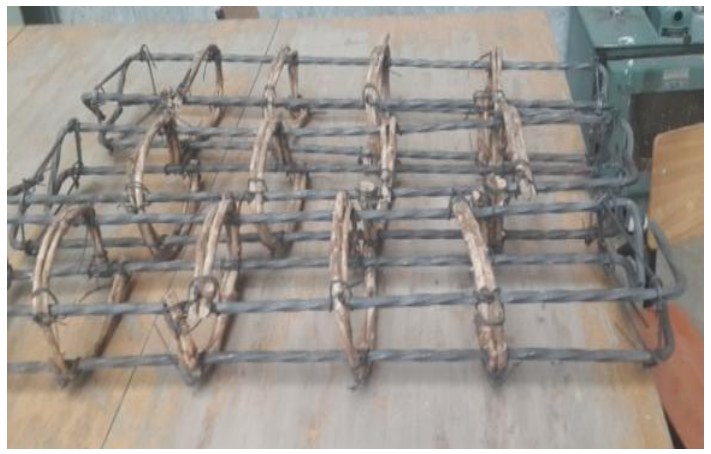

Figure 1: Fixed L.buchananiias shear reinforcements

\section{Experimental Programme}

The experimental programme entailed determination of compressive strength of a concrete cube, tensile strength of L. buchananiistemand shear, bending strength, deflection and failure mode of L.buchananii and steel shear reinforced concrete beams.

\subsection{Tensile strength of Landolphiabuchananii}

Tensile strength was determined in accordance to BS 3731957.Tensile test method of tension parallel to the fibers was performed. Load was applied on $2 \mathrm{~cm}$ face to the test pieces at a constant head speed of $1.27 \mathrm{~mm} / \mathrm{min}$. The specimen was shaped as shown in Figure 2 to allow failure at gauge section.
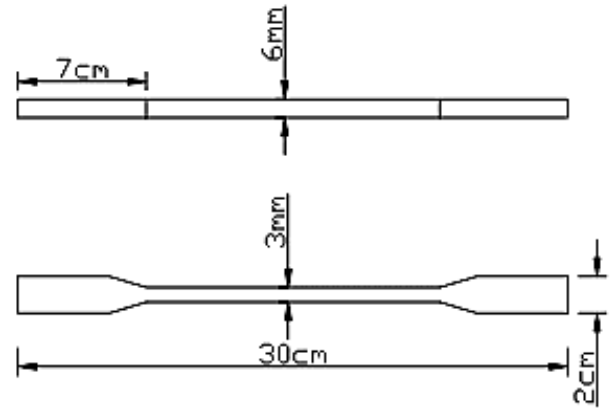

Figure 2: Test piece for tensile strength test

\subsection{Beam Test and Cube Compressive Test}

Beam test and compressive test was conducted after 28 days of curing. The test conducted was based on three point loading arrangement with span between the supports centres being $900 \mathrm{~mm}$ as shown in Figure 3. Displacement transducer was used to measure deflection at mid-span. Loading was applied at mid-span of the beam gradually to failure while recording load and deflection at intervals. First crack load and crack type was also observed.

Compressive test was performed on concrete cubes specimen after 28 days and their respective strengths determined.

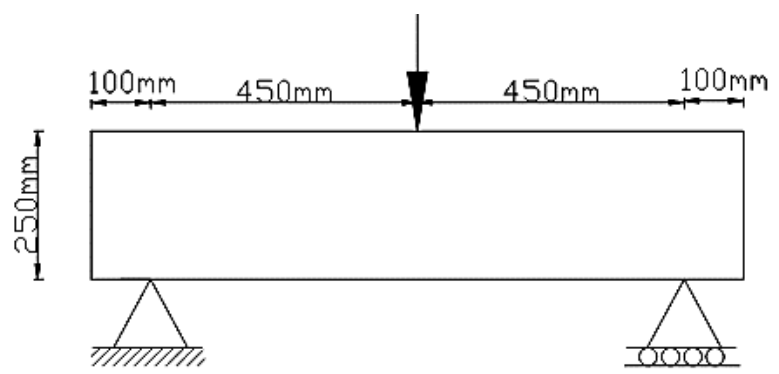

Figure 3: Bending test setup

\section{Test Results and Discussion}

\subsection{Tensile strength of Landolphiabuchananii}

The average tensile strength for Landolphia buchananii stem was $87.2 \mathrm{~N} / \mathrm{mm}^{2}$ which is around $35 \%$ that of conventional mild strength steel usually used as shear reinforcement. From Figure 4 it can be seen that failure occurred near the portion prepared for grip.

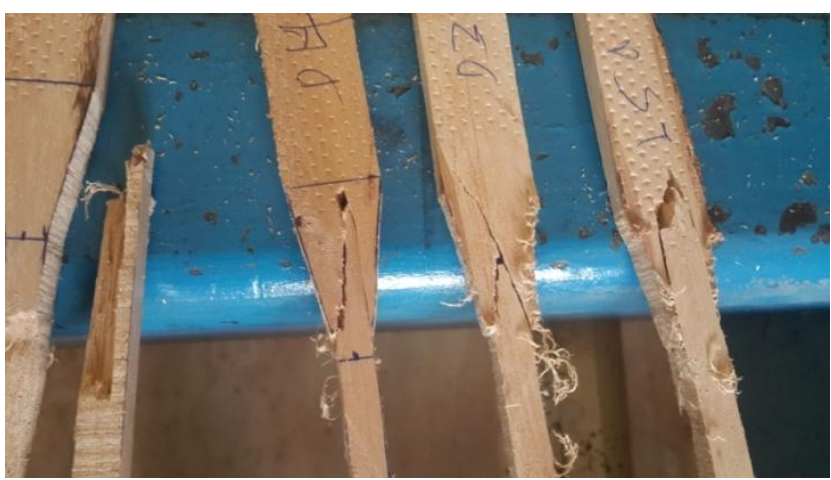

Figure 4: Mode of failure of tensile test samples 


\section{International Journal of Science and Research (IJSR) \\ ISSN (Online): 2319-7064 \\ Index Copernicus Value (2013): 6.14 | Impact Factor (2014): 5.611}

\subsection{Compressive strength}

Mean compressive strength of concrete cubes at the age of 28 days was $20.8 \mathrm{~N} / \mathrm{mm}^{2}$ which was higher than the target strength of $20 \mathrm{~N} / \mathrm{mm}^{2}$. The mean slump value was $34 \mathrm{~mm}$ which was between $30-40 \mathrm{~mm}$.

\subsection{Beam Test}

The findings in Fig.5 show the load-deflection curves for steel and Landolphiabuchananii reinforced concrete. All the curves generally exhibit non-linearity for all the loads to failure. From Table 1, Landolphiabuchananii reinforced concrete beams failed between $58 \mathrm{kN}$ and $79.8 \mathrm{kN}$ while that of steel reinforced beam failed at $81.3 \mathrm{kN}$ with failure load coincide with the last point of the curves. Yield deflection for L.B.1x6, L.B.1x8, L.B.2x10, L.B.2x13 and steel $1 \times 6$ was $2.9,0.69,5.9,3.36$ and $8.1 \mathrm{~mm}$ while their first crack loads deflection was 1.35, 0.49, 0.25, 1.98 and $0.9 \mathrm{~mm}$ respectively. Failure loads for Landolphiabuchananii reinforced concrete beams increased with increase in the area of shear reinforcement of Landolphiabuchananii.

From Table 1, it can be seen that the bending stress and shear stress of Landolphiabuchananii reinforced concrete beams increased with increase in area of shear reinforcement of Landolphiabuchananii. It can be seen that the bending stress and shear stress of the Landolphiabuchananii beam with the largest area of shear reinforcement (L.B. 2x13) was around $94 \%$ that of steel reinforced beam (steel 1x6) as shown in Figure 6 and 7 .

In accordance to BS 8110 beams are considered to have failed when deflection exceeds the ratio span/360 which was $2.5 \mathrm{~mm}$. Load at this deflection was $52 \mathrm{kN}, 65 \mathrm{kN}, 32$, $\mathrm{kN}$ and $65 \mathrm{kN}$ for L.B.1x6, steel 1x6, L.B.2x10 and L.B.2x13 respectively. L.B.1x8 load reached maximum before the deflection limit. It can be seen that the load at this deflection is same for steel1x6 and L.B.2x13.

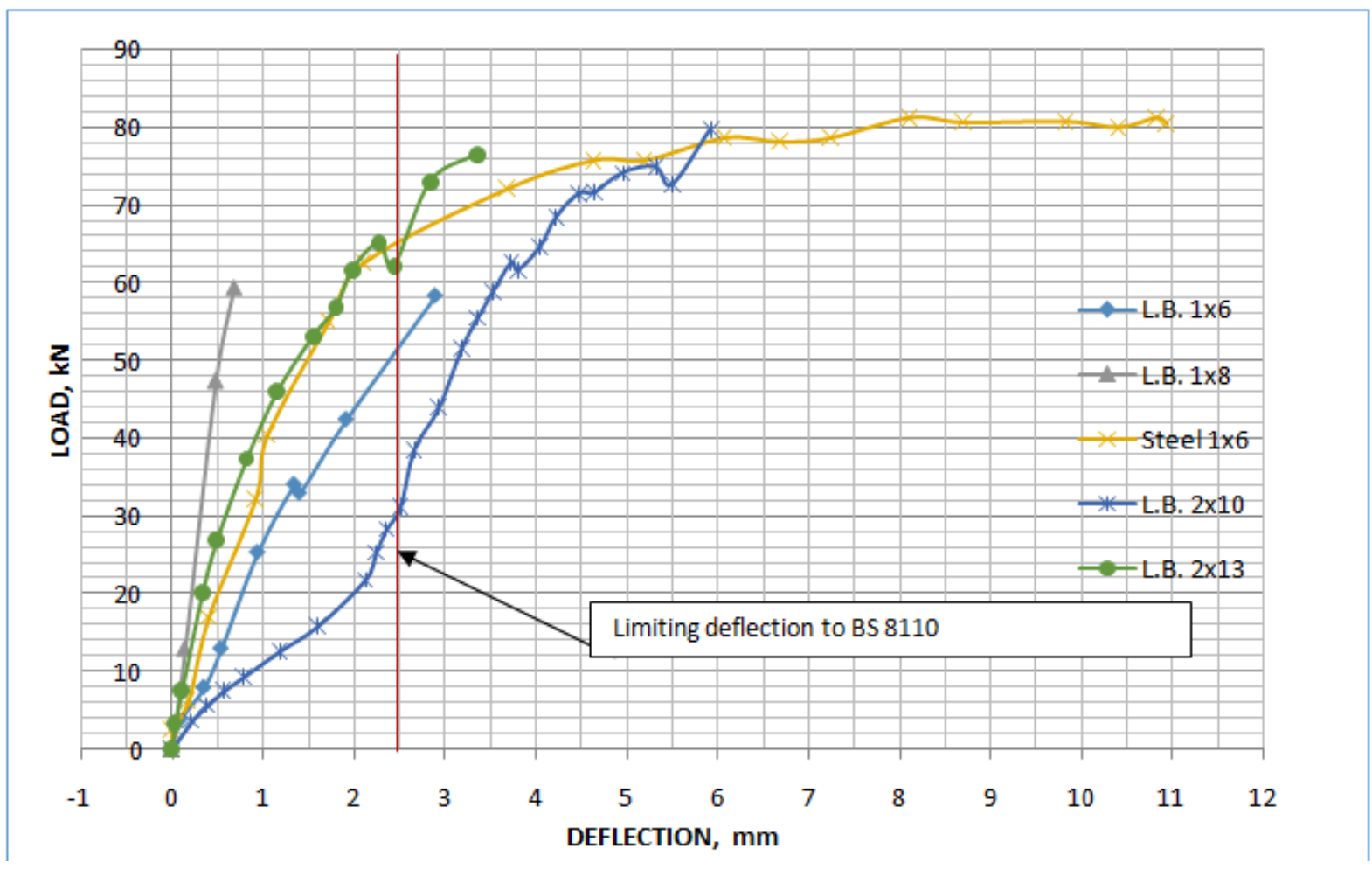

Figure 5: Load-deflection curves for shear reinforced beams.

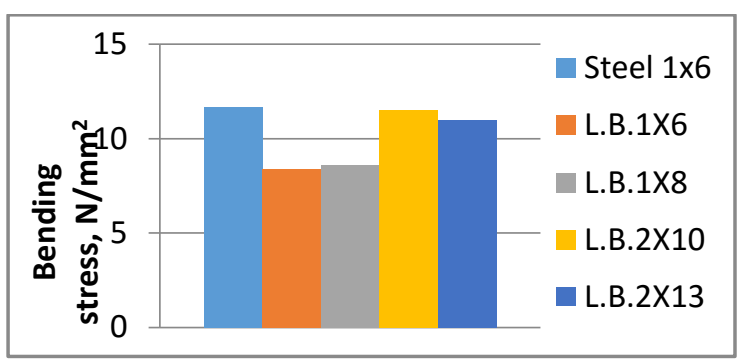

Figure 6: Comparison of bending strengths of shear reinforced concrete beams 


\section{International Journal of Science and Research (IJSR) \\ ISSN (Online): 2319-7064}

Index Copernicus Value (2013): 6.14 | Impact Factor (2014): 5.611

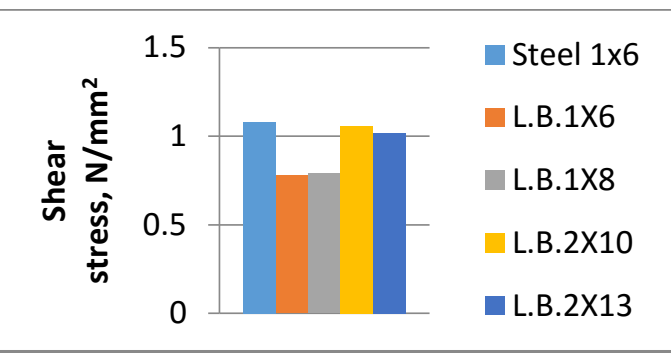

Figure 7: Comparison of shear strengths of shear reinforced concrete beams

\subsection{Failure Modes}

The results presented in Table 1 are first crack loads, ultimate loads, first crack load deflections, second crack load deflections, shear stresses and bending stresses of the reinforced concrete beams at the age of 28 days. From Table 1 , it can be seen that the load carrying capacity of the beam depended on the area of shear reinforcement i.e. the larger the area of shear reinforcement the larger the load carrying capacity.

Shear failure is noted in the entire Landolphiabuchananii reinforced concrete beam with crack occurring from the bottom side of the beam near the support diagonally to the point of loading. From load-deflection curves (Figure 5) and the failure pattern L.buchananii reinforced beams (Figure 9, 11, 13 and 15) as compared to that of the steel reinforced beam (Figure 17), it can be noted that the beams failed in shear. When the region of failure crack was examined (Figure 8, 10, 12 and 14), the L.buchananii stem was unbroken, this can suggest that there was a poor bond between L.buchananii and concrete which led to beam failing in bonding or that the reinforcement was flexible enough to not to break. The flexibility of Landolphiabuchananii shear reinforcements can be attributed to low modulus of elasticity.

Table 1: Beam test results for $L$. buchananiias a shear reinforcement.

\begin{tabular}{|c|c|c|c|c|c|c|c|}
\hline \multicolumn{8}{|c|}{ L. buchananii as shear reinforcement } \\
\hline Beams & \multicolumn{2}{|c|}{ Deflection, mm } & \multicolumn{2}{|c|}{ Load, kN } & \multicolumn{2}{|c|}{ Stresses } & \multirow[b]{2}{*}{ Mode of failure } \\
\hline & 1st crack & Max. & 1st crack & Max. & Bending stress, $\mathrm{N} / \mathrm{mm}^{2}$ & Shear stress, $\mathrm{N} / \mathrm{mm}^{2}$ & \\
\hline Steel 1x6 & 0.9 & 8.11 & 32.2 & 81.3 & 11.7 & 1.08 & Shear +flexure \\
\hline L.B.1x6 & 1.35 & 2.9 & 34.1 & 58.4 & 8.4 & 0.78 & Shear \\
\hline L.B.1x8 & 0.15 & 0.69 & 47.5 & 59.5 & 8.6 & 0.79 & Shear \\
\hline L.B. $2 \times 10$ & 2.94 & 3.9 & 31.2 & 79.8 & 11.5 & 1.06 & Shear \\
\hline L.B. $2 \times 13$ & 1.98 & 3.36 & 61.3 & 76.5 & 11.0 & 1.02 & Shear \\
\hline
\end{tabular}

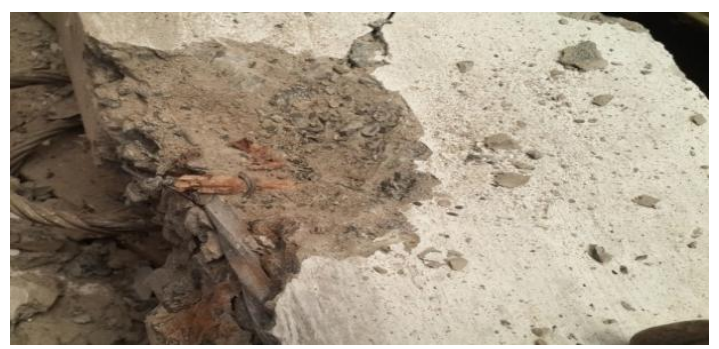

Figure 8: Unbroken shear reinforcement for L.B.1x6 beam

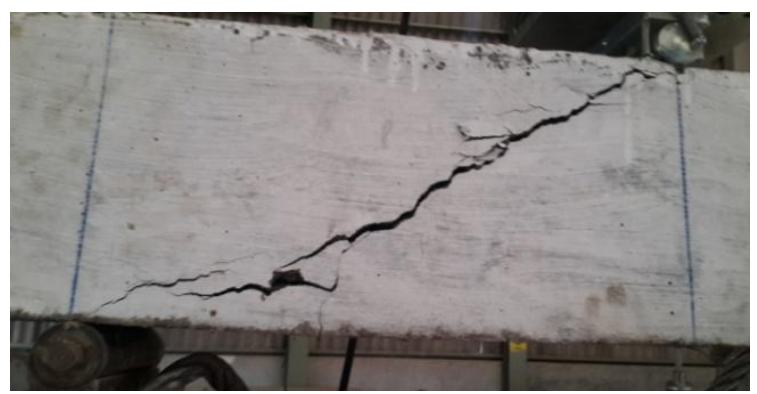

Figure 9: Failure pattern of L.B.1x6 beam

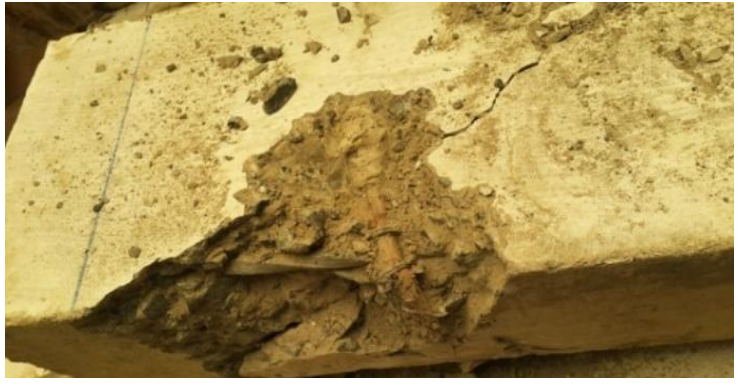

Fig.10: Unbroken shear reinforcement for L.B.1x8 beam

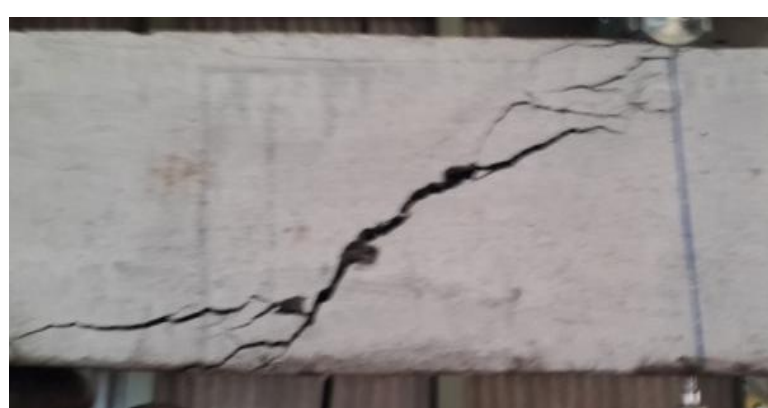

Figure 11: Failure pattern of L.B.1x8 beam 


\section{International Journal of Science and Research (IJSR) \\ ISSN (Online): 2319-7064}

Index Copernicus Value (2013): 6.14 | Impact Factor (2014): 5.611

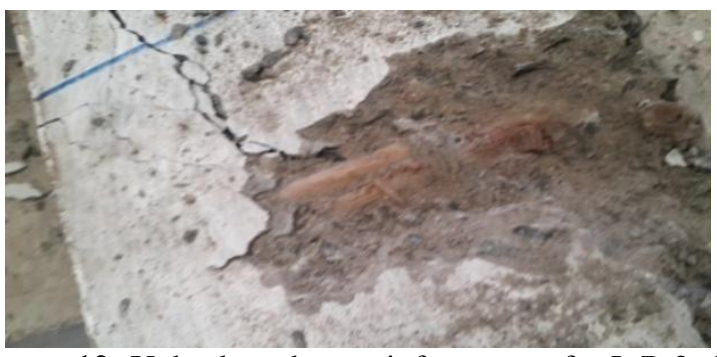

Figure 12: Unbroken shear reinforcement for L.B.2x10 beam

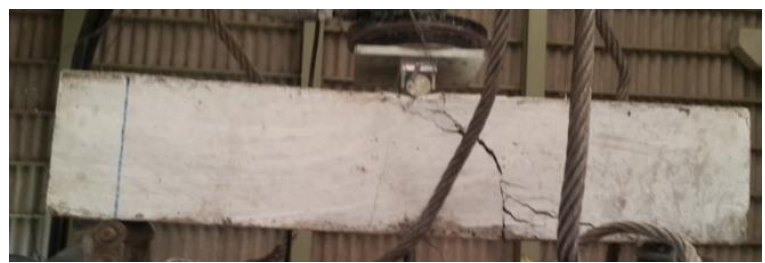

Figure 13: Failure pattern of L.B.2x10 beam

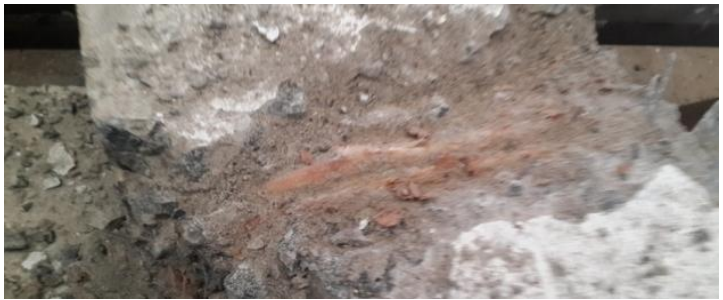

Figure 14: Unbroken shear reinforcement for L.B.2x13 beam

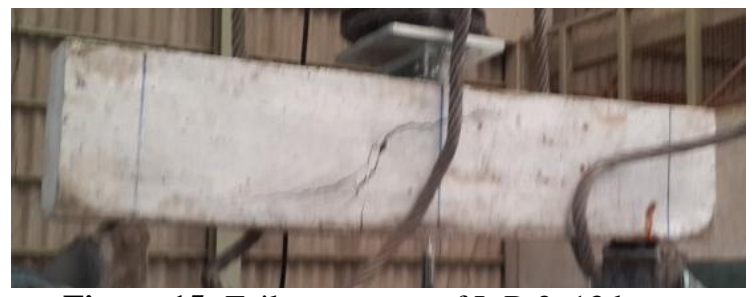

Figure 15: Failure pattern of L.B.2x13 beam

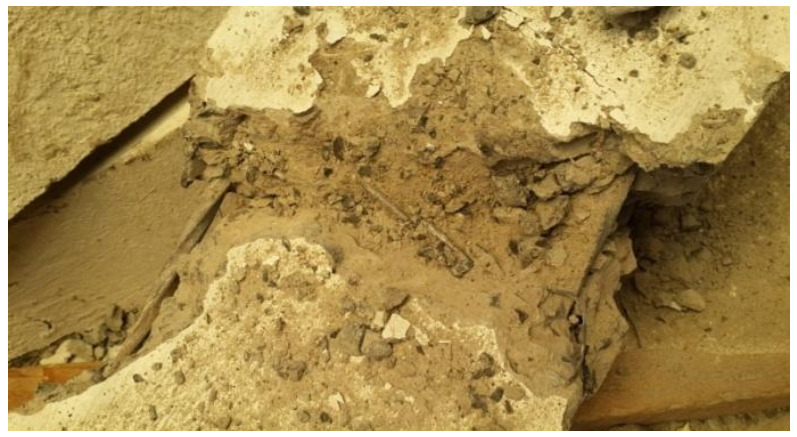

Figure 16: Snapped shear reinforcement for steel 1x6 beam

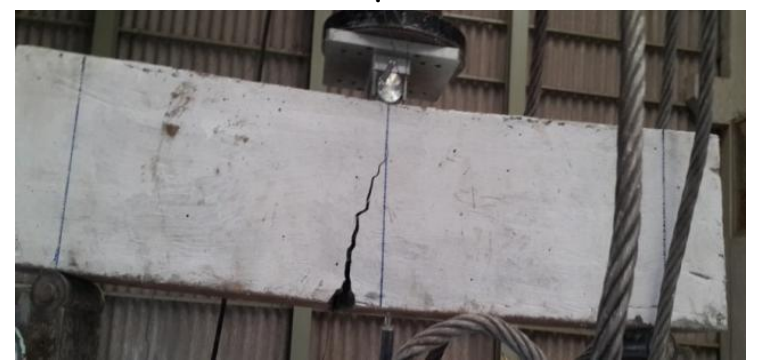

Figure 17: Failure pattern of Steel1x6 beam

\section{Conclusion}

From this study of Landolphiabuchananii shear reinforced concrete beams, it can be seen that Landolphiabuchananii improves the load carrying capacity of the beams when used as shear reinforcement. The following conclusions can be drawn from the study:

a. Failure loads of the beams increased with increase in the size/area of shear reinforcement of Landolphiabuchananii. Failure load of the beam with smallest and largest area of shear reinforcement being $58 \mathrm{kN}$ and $79.8 \mathrm{kN}$ respectively.

b. Bending stress and shear stress of Landolphiabuchananii reinforced concrete beam increased with increase in area of shear reinforcement of Landolphiabuchananii. Bending stress and shear stress of the beam with the largest area of shear reinforcement of L. buchananii (L.B. 2x13) was around $94 \%$ that of steel reinforced beam (steel 1x6).

c. The tensile strength of Landolphiabuchananii was lower than that of conventional mild steel by about $65 \%$.

d. Mode of failure of Landolphiabuchananii shear reinforced concrete beams was due to shear and failure due to bonding between concrete and L. buchananii.

e. There is need to investigate the bonding behavior of $L$. buchananiiwhen used as reinforcement of concrete

\section{Reference}

[1] Harish Sakaray, N.V. Vamsi Krishna Togati and I.V.Ramana Reddy, "Investigation on properties of bamboo as a reinforcing material in concrete", International Journal of Engineering Research and application (IJERA). Vol.2, ISS01 pp. 077-083, 2012.

[2] Adom-Asamoah Mark, Afrifa Owusu Russell, "A comparative study of Bamboo reinforced concrete beams using different stirrup materials for rural construction", International Journal of Civil and Structural Engineering. ISSN 0976 - 4399 .Volume 2, No 1, 2011.

[3] Amada, S. and Untao, S. (2001), "Fracture Properties of Bamboo", Composites Part B, Vol. 32, pp 451-459.

[4] Ghavami, K., "Bamboo as reinforcement in Structural Concrete Elements", Elsevier Cement Concrete Composites 1995; 17(4):281-8, 1995.

[5] M.M. Rahman, M.H. Rashid, M.A. Hossain, M.T. Hasan and M.K. Hasan, "Performance evaluation of bamboo reinforced concrete beam", International journal of engineering and technology, (IJET-IJENS) Vol. 11, No.21, 2011.

[6] Tara Sen, H. N. Jagannatha Reddy, "Application of Sisal, Bamboo, Coir and Jute Natural Composites in Structural Up-gradation", International Journal of Innovation, Management and Technology, Vol. 2, No. 3, 2011.

[7] M.D. Ahsan Sabbir, S.M. Ashfaqul Hol, and Saiada Fuadi Farcy, "Determination of Tensile property of Bamboo for using as a potential reinforcement in the concret", International Journal of Civil and Environmental Engineer Vol. 11 No: 05, 2011.

[8] Manguriu, G., Oyawa, W., and Abuodha, S., "Physical and mechanical properties of mangrove from Kilifi in

\section{Volume 5 Issue 3, March 2016}




\section{International Journal of Science and Research (IJSR) \\ ISSN (Online): 2319-7064}

Index Copernicus Value (2013): 6.14 | Impact Factor (2014): 5.611

Kenya", Global Engineers\& Technologists Review, 3, 1-5, 2013.

[9] Kallemana Aze Kerte, Timothy Nyomboi, Walter Oyawa, "Structural performance of mangrove reinforced concrete beams", International Journal of Engineering Sciences \& emerging Technologies. Vol. 7 No 1, 2014.

[10]Charles K. Kankam, Brigitte Odum-Ewuakye, "Structural behaviour of babadua reinforced concrete beams", Elsevier construction and building materials, 13: 187-107, 1999.

[11] Obilade I.O., Olutoge F.A., "Flexural characteristics of rattan cane reinforced concrete beams". The International Journal of Engineering and Science (IJES), 3(6): 38-42, 2014.

[12] Akinyele J. O., OlutugeF. A., "Properties of Rattan Cane Reinforced Concrete Façade Subjected to Axial Loading", Journal of Civil Engineering and Architecture, 5(11): 1048-1052, 2011.

[13] Baskaran K., Mallikarachchi H.E., Jayasekara M.J.L.M., and Madushanka G.A.T., "Feasibility of using palmyrah strips as reinforcing material in cost effective houses", Hindawi Publishing Corporation Journal of Construction Engineering, Article ID 589646, 2014

[14] National research council of the natural Academies (NRCNA). "Lost crops inAfrica Volume III: Fruits", The National Academies press Washington D.C.2008.

[15] Persoon J.G.M., Van Dilts F.J.H., Kuijpers R.P., Leeuwenberg A.J.M and Vonk G.J.A., "The African species of Landolphia P. Beauv. Series of revisions of Apocynaceae" XXXIV. First edition. Kluwer Academic Publishers, Dordrecht/ Boston/ London.1992.

[16]BS 882,"Specification for aggregates from natural sources for concrete". UK, London, 1992.

[17]BS 8110-1, "Code of practice for design and construction". UK, London, 1997.

[18] BS 373, "Methods of testing small clear specimen of timber", UK. London, 1957.

[19]BS 8500, "Method of specifying and guidance for the specifier", UK, London, 2006 